\title{
Investigating Built Environment Indicators to Develop a Local Walkability Index
}

\author{
${ }^{*}$ B.sc. Menna Tarek (i) P , 2 Prof. Dr. Ghada Farouk Hassan if \\ ${ }^{3}$ Prof. Dr. Abeer Elshater (1) D , ${ }^{4}$ Dr. Mohamed Elfayoumi $\mathbb{E}$ \\ 1, 2, 3 and 4 Ain Shams University, Faculty of Engineering, Cairo, Egypt. \\ E-mail 1: menna.tarek@eng.asu.edu.eg,E-mail 2: Ghadafhassan@eng.asu.edu.eg \\ E-mail 3: abeer.elshater@eng.asu.edu.eg ,E-mail 4: $m$ fayoumi@eng.asu.edu.eg
}

\begin{tabular}{l}
\hline ARTICLE INFO: \\
\hline Article History: \\
Received 8 June 2021 \\
Accepted 20 August 2021 \\
Available online 29 August 2021 \\
\hline Keywords: \\
Local Walkability Index; \\
Pedestrian Walking \\
Behaviour; \\
Urban Design; \\
Mixed-use Street, \\
Cairo.
\end{tabular}

This article is an open access
article distributed under the terms and
conditions of the Creative Commons
Attribution (CC BY) license
This article is published with open
access at www.ijcua.com

\section{ABSTRACT}

Many studies have been conducted over the last 20 years to determine and measure factors that affect the walkability of city streets. Walkability is an essential factor in deciding whether a city is green or sustainable. This paper creates a comprehensive walkability index by analysing built environmental indicators that affect walkability. This research was conducted on mixed land use streets in Cairo, Egypt, combining the results from an online survey and a walkability assessment model developed by multi-criteria decision analysis techniques. The results were based on a three-pillar approach starting with the theoretical background to frame the walkability indicator, numerical assessment over the Egyptian cases using a multi-criteria decision-making (MCDM) technique and a qualitative user perception survey. Our results confirm that determining to what extent Cairo's streets are walkable is crucial to enhancing pedestrians' perceptions of the walking environment. Furthermore, the results illustrated the essential factors within the built environment indicators that influence pedestrian walking behaviour.

JOURNAL OF CONTEMPORARY URBAN AFFAIRS (2021), 5(2), 235-251. https://doi.org/10.25034/ijcua.2021.v5n2-7

www.ijcua.com

Copyright $(\mathcal{C}$ B.Sc. Menna Tarek, Prof. Dr. Ghada Farouk Hassan, Prof. Dr. Abeer Elshater, Dr. Mohamed Elfayoumi.

\section{Introduction}

Research describes the essential need for the start and endpoint of any walking experience (Capitanio, 2019; Caymaz, 2019). Walking is also the only way several people can approach everyday activities (Chapman \& Olson, 2017; Hussein, 2018; Ferrer, Ruiz, \& Mars, 2015). However, the streets and public spaces once meant for pedestrians are being degraded and invaded by private cars, pulling an active social life from residents that formerly walked on the streets (Balsas, 2021; Krambeck

*Corresponding Author:

Ain Shams University, Faculty of Engineering, Cairo, Egypt.

Email address: menna.tarek@eng.asu.edu.eg 
\& Shah, 2006). Forsyth and Southworth (2008) argue that walkability is the foundation of a sustainable city, and it comes with substantial social, environmental and economic benefits. Recently, walkable environments have been carefully considered in urban design and public health (Ewing \& Handy, 2009; El Helou, 2019). One of the most critical aspects of city planning is walking. Research has linked walking to reduced obesity and the gain of other health benefits (Abedo, Salheen, \& Elshater, 2020). For example, walking reduces cardiovascular disease, diabetes and hypertension; it also decreases traffic congestion, reduces carbon emissions, noise and pollution (Alfonzo, 2005; Banister, 2007; Capitanio, 2019; López \& Wong, 2019; Pucher \& Buehler, 2010). In addition to creating 'liveable communities,' walkability is an essential parameter to enhance the quality of life, safety and comfort (Elshater, Abusaada, \& Afifi, 2019).

Over the past 20 years, definitions of terms such as 'walkability' and 'walk-friendly communities' have become prominent in the literature (Alawadi, Striedinger, Maghelal, \& Khanal, 2021). The connection between these terms with the built environment has been investigated using different tools (Shaaban, 2019; Southworth, 2005). In the current research, walkability is the extent to which the built environment promotes safety and direct access to destinations while reducing travel time and effort and providing a comfortable and appealing visual environment (Dill, 2004).

Several pieces of research classify the indicators that support walkable, friendly environments (LO, 2009; Forsyth \& Southworth, 2008; Balsas, 2021; Reisi, Nadoushan, \& Aye, 2019). Since 2009, most of the walkability studies focus on macroscale indices constructed from objective, measurable variables. However, these studies neglect the microscale indicators that could be subjective (Arellana, Alvarez, Oviedo, \& Guzman, 2021). Furthermore, few studies combine several indicators to generate a single walkability index (WI). The available data is limited, and no previous research has focused on the methods used to determine the built environment's walking potential in Egyptian cases. More research is needed to address this issue (Abedo, Salheen, \& Elshater, 2020; Abussada \& Elshater, 2021b).
Regarding walkability in the Egyptian context, definitions and contributing elements require further investigation (Abedo, Salheen, \& Elshater, 2020). The rapid deterioration of Egypt's street life is apparent in overcrowded cities like Cairo, with mixed-use/commercial streets becoming more common (Abussada \& Elshater, 2021b). Building on the gap in the literature, studies must assess how to integrate the macro- and micro-scale indicators into walkability indices.

A definitive link between walkability and built environment has been challenging to prove. Here, we see a challenge identical to the traditional problem of the standard governmental solution: to increase street capacity to minimise road congestion by widening streets and narrowing sidewalks (Wahba, Kamel, Kandil, \& Fadda, 2021). However, according to the best countries statistics in 2021 released by US News, Egypt is ranked 51 in overall quality of life, which is considered a poor ranking (US News, 2021). Therefore, the absence of public spaces, especially the sidewalks, expanding car lanes at the costs of sidewalks, the lack of walkways, or being congested (UN Habitat, 2013) are central issues that negatively affect local walkability and, therefore, reduce the day-today quality of life.

There are unanswered questions about the reliability of the built environment in Egypt and its effect on walkability. Therefore, this study addresses the specific research question, "What are the methods that can be applied to formulate a revised version that fit the Egyptian cases?"

This research focuses on the urban streets of Cairo City from the pedestrian-use perspective. The purpose of the present study is to generate a local walkability index (LWI) for urban highways in Cairo, Egypt, considering the restrictions on constructing $L W I$ from actual measurements of built environment indicators. In addition, the study aims to explore the built environment factors that would make the streets of Cairo better places for walking and more adaptable to being used by pedestrians. With this aim in mind, it would be easy to determine the challenges that would stand in the way of achieving 'walkable streets' in Cairo and how to overcome those challenges.

The measurement of the walkability in the Egyptian built environment is the focus of this research. The method used three mixed-use 
streets in Cairo. First, a literature review was the basis for developing a comprehensive walkability index using built environment indicators that influence walkability. Second, the authors conducted intense site observation and online questionnaires to analyse the built environment indicators and the users' satisfaction and walking perception in Cairo's three cases. Third, the selected built environment factors were weighted, normalised, and then aggregated to a single WI for each case with the aid of a multi-criteria decision-making (MCDM) technique using the analytical hierarchy process (AHP).

This paper adds to the present literature by developing a new composite indicator for a comprehensive framework that could enhance walkability, using macro and microscale built environment parameters to assess walkability and create LWI in Cairo.

The paper is structured into five parts after this introduction (Figure 1). The second part illustrates the selected methods conducted in the current work to answer the research questions. The third part shows the results of scanning relevant literature on Scopus, the Web of Science, and reports, ending with the index investigated in case studies. The fourth part presents the results of the mathematical development of the index and data analyses. Finally, the fifth and sixth sections provide deductive arguments about the LWI ranking results in the Egyptian cases and provide thoughts on directions for future work.

\section{Material and Methods}

This section introduces a conceptual framework for comparing walking conditions in different city zones using a pedestrian accessibility evaluation. Second, it explains the research field and context used for testing the proposed conceptual framework.

\subsection{Theoretical Background: Framing the Indicators of Walkability}

In this section, we define the term walkability and the influencing factors. To elucidate a walkable environment, the authors outline the assessment tools and determine the relationship between the built environment and walking behaviour. The literature review depends on two sources. First, articles in Web of Sciences and Scopus; second, published reports on the relevant topic of walkability, liveability and quality of life.

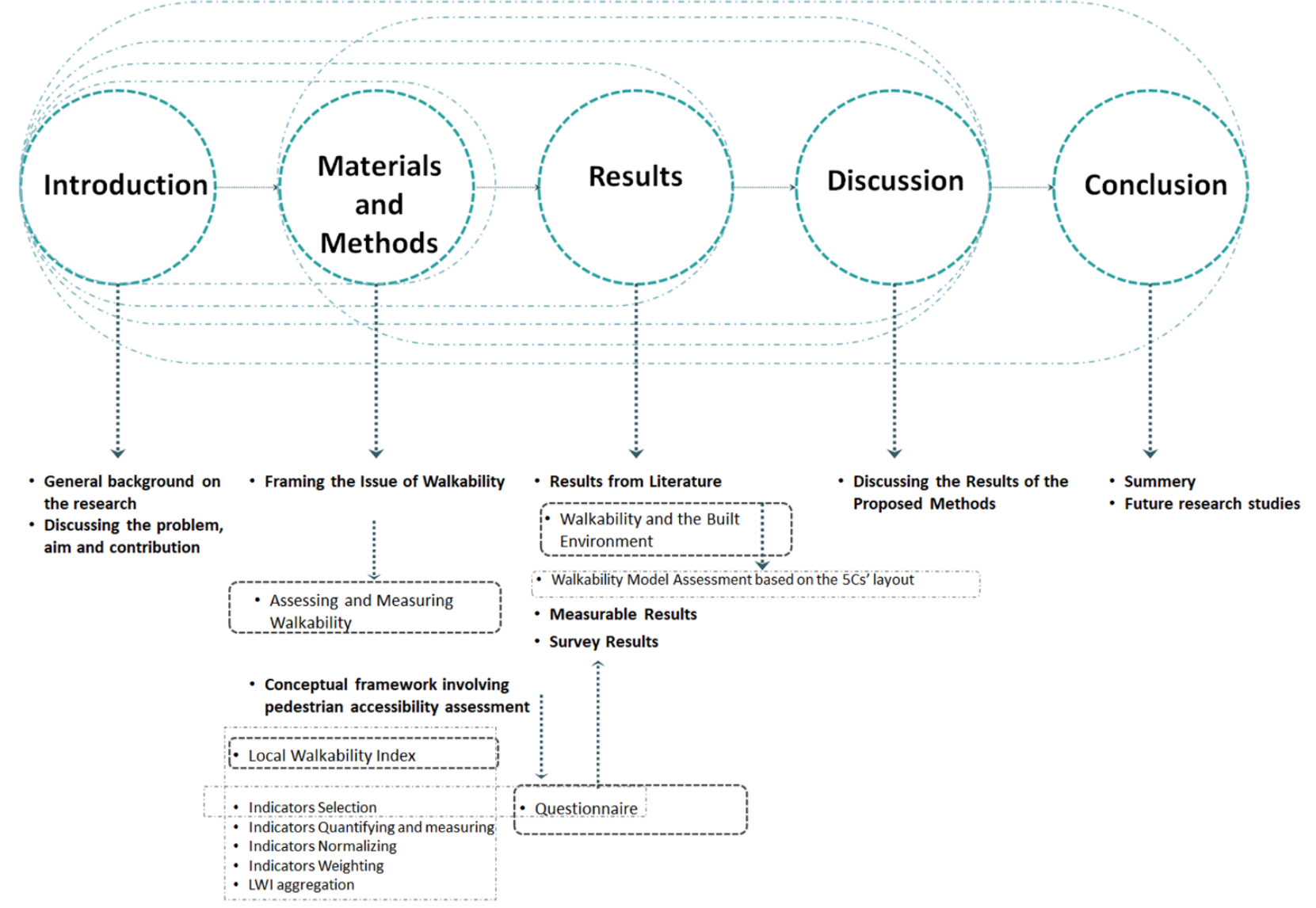

Figure 1. Research structure. 
The results show that many tools have emerged to assess the quality of the built environment or the walking environment (Abusaada, Vellguth, \& Elshater, 2019; Ewing \& Handy, 2009; Leslie, Frank, Owen, Bauman, \& Hugo, 2007). These tools gauge whether the built environment attributes are related to different physical activity levels, especially walking (Albers, Wright, \& Olwoch, 2010; Alawadi, Striedinger, Maghelal, \& Khanal, 2021; Department of Public Health, 2008). Like previous studies, literature was a secondary data source, and it illustrated the importance of various techniques and factors and existing measurement tools (Aghaabbasi, Moeinaddini, Shah, \& Asadi-Shekari, 2017).

\subsection{Study Area}

Cairo is a large city with over 20 million people (CAPMAS, 2019). As documented in the literature, walkability is greatly affected by socioeconomic level and the built environment, including land use, urban form, street network, and landscape design (Alawadi, Striedinger, Maghelal, \& Khanal, 2021). Therefore, three case studies were selected based on diversity in their socioeconomic status, built form, street systems and demographic composition. Figure 2 shows the three neighbourhoods on a google earth map.

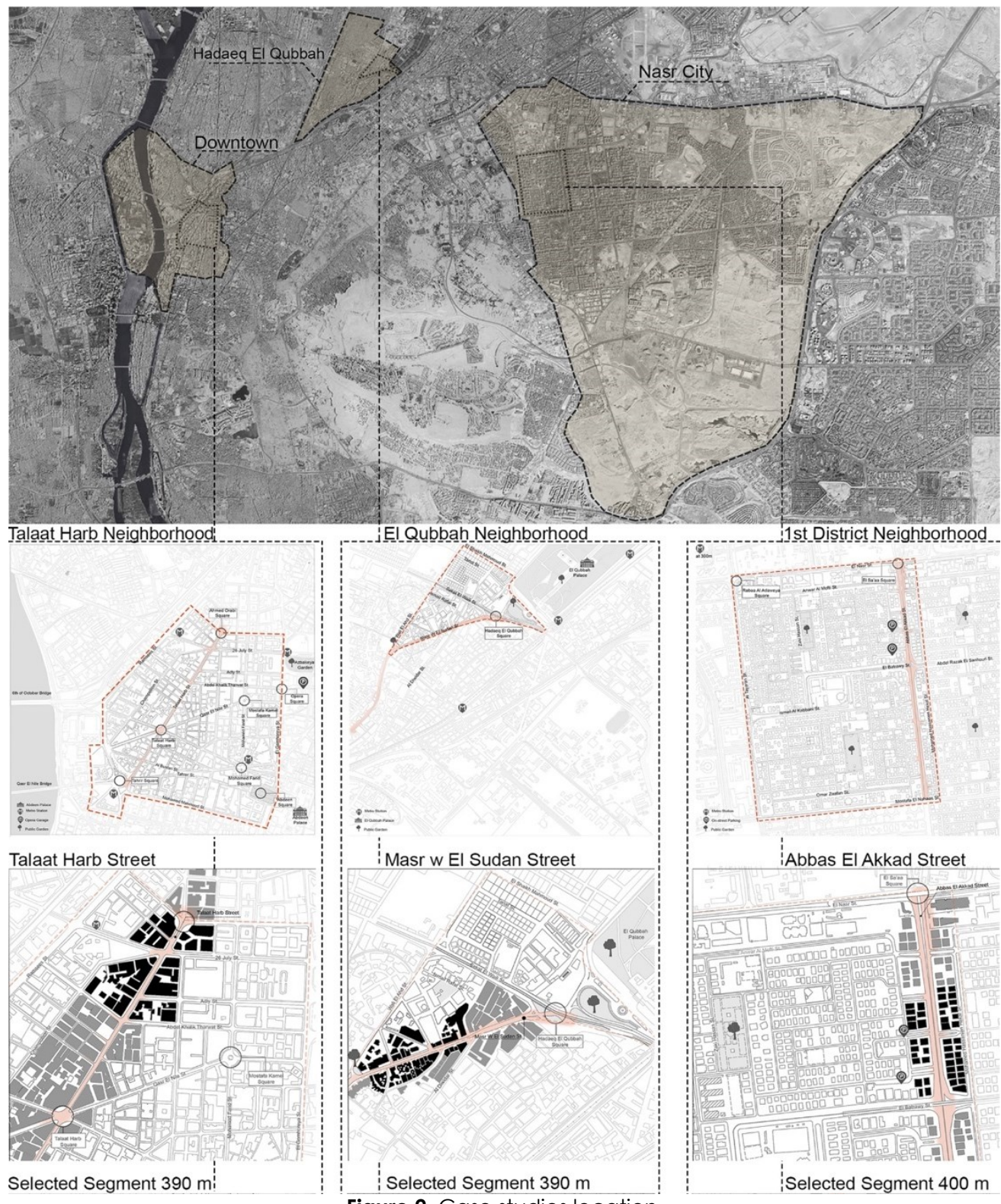

Figure 2. Case studies location. 
The first case is Downtown (1798-1952), the second is Hadaeq El Qubbah (882-1908), and the third is Nasr City (1952-1987). Downtown is considered a medium socioeconomic area and the Cairo CBD. Hadaeq El Qubbah is an old urban community with historical background from 882 till 1908 when it became known as Hadaeq El Qubbah. It is now considered as a below medium-class area. While Nasr City is an intermediate urban community, it is considered an above mediumclass area based on the apartment prices.

\subsection{Mathematical Development of the Walkability Index}

After selecting the different neighbourhoods to perform the measurement, it was necessary to choose the streets for data collection (Soba, Ersoy, Altınay, Erkan, \& Şik, 2020), using criteria such as highly mixed land use (López, Toan, \& Wong, 2020; Ewing, et al., 2011) and car parking along the streets. The criteria also include distances between $200 \mathrm{~m}$ and $400 \mathrm{~m}$ long (Pallas, 2010).

Converting the indicators first before summing the dimensionless values is critical when working with a variety of indicators. Previous research describes this process as normalisation (Nardo, Saisana, \& Saltelli, 2005). Our selected indicators cover both positive and negative effects on the ability to walk in the case studies. Similar to previous research addressing positive and negative indicators, the normalisation equation differed (Reisi, Nadoushan, \& Aye, 2019). Equations (1) and Equation (2) show the normalisation equations for positive and negative indicators (Krajnc \& Glavič, 2005).

$\begin{aligned} I^{+}{ }_{N} & =\frac{I^{+}-I^{+}{ }_{\min }}{I^{+} \max -I^{+}{ }_{\min }} \\ I^{-}{ }_{N} & =\frac{I^{-} \max -I^{-}}{I^{-} \max -I^{-}{ }_{\min }}\end{aligned}$

Where $I^{+} \mathrm{N}$ is for the normalised positive indicator, and $\mathrm{I}_{\mathrm{N}}$ represents the normalised negative indicator. Imin was the minimum value of indicator considering the three streets, Imax was the maximum value of indicator over the three streets.

Previous research has attempted to establish weighted walkability indices using various techniques to prevent equal weighting in their development (Albers, Wright, \& Olwoch, 2010). Specific mathematical relations are used to assign weights (Organisation for Economic Cooperation and Development, 2008). In this study, we used the analytical hierarchy process (AHP) (Saaty, 1980). The AHP approach decomposes complicated situations into a hierarchical structure of the research aims and related criteria and sub-criteria.

AHP conducts paired comparisons for the indicators in each level of the hierarchy for obtaining weights for indicators. Pairwise comparisons are performed between pairs of indicators, demonstrating the relative relevance of one indication to the other, and quantified based on experts' judgments. Indicator weights and priorities were gained from experts and researchers from the reviewed secondary data and estimated from previous studies or other indicators measurements.

This research suggested an indicator aggregation and index composition after assigning a weight to each of the indicators. The aggregation occurred through the weighted linear combination (WLC) method shown in Equation (3). This method is an overlaying technique that considers the normalised values and relative weights of indicators in an aggregation (Al-shabeeb, 2015):

$$
L W I=\sum W_{i j} \cdot X_{i j}
$$

Where LWI is the Local Walkability index. $W_{i}$ stands for the weight of indicator $\boldsymbol{i}$ in parameter $\boldsymbol{j} . \mathrm{X}_{\mathrm{ij}}$ is the normalised value of indicator $\boldsymbol{i}$ in parameter $\boldsymbol{j}$.

The normalised value of each indicator for each parameter was multiplied by the relative weights of the indicators extracted in the previous stage using AHP. Next, the relative weights of the indicators collected using AHP in the previous stage multiplied each parameter's normalised value. Finally, a subindex was created by combining the weighted values of indicators in each parameter. The weight of each type was then multiplied by the sub-index value and combined into a single LWI (Aghaabbasi, Moeinaddini, Shah, \& AsadiShekari, 2017; Gallin, 2001). Table 1 shows the interpretation of the LWI scores, ranges and the level of required improvements (LRI) at each grade (Aghaabbasi, Moeinaddini, Shah, \& Asadi-Shekari, 2017). 
Table 1. LWI interpretation Source: (Aghaabbasi, Moeinaddini, Shah, \& Asadi-Shekari, 2017)

\begin{tabular}{|c|c|c|c|c|}
\hline LRI & LWI & Grade & Condition & Description \\
\hline 1 & $80 \leq \mathrm{LWI} \leq 100$ & A & Very Good & Streets deliver great services for its users \\
\hline 2 & $60 \leq \mathrm{LWI}<80$ & B & Good & Streets adequately serve the users \\
\hline 3 & $40 \leq \mathrm{LWI}<60$ & C & Regular & Streets serve the users adequately \\
\hline 4 & $20 \leq \mathrm{LWI}<40$ & $\mathrm{D}$ & Poor & Streets do not support the users \\
\hline 5 & $0 \leq \mathrm{LWI}<20$ & $\mathrm{E}$ & Awful & $\begin{array}{l}\text { Streets are not provided by appropriate service to } \\
\text { satisfy the users }\end{array}$ \\
\hline
\end{tabular}

This research used internal consistency to examine the applicability of the proposed tool's measurements. Cronbach's alpha was used to evaluate the consistency of this tool as it calculates how accurately a group of items measures a single unidimensional factor (Arellana, Saltarín, Larrañaga, Alvarez, \& Henao, 2020). An alpha value of 0.7 or higher shows reliability (Cortina, 1993).

\subsection{Qualitative Data Collection}

After selecting the indicators, the authors visited the streets multiple times to gauge the 26 selected indicators in the three streets. Table 2 shows the proposed model of walkability assessment based on the 5Cs' layout and each indicator's measurement and quantification. The survey was a pragmatic approach based on qualitative data to assess user's perception of their neighbourhood streets (Silva, Saraiva, Loupa-Ramos, \& Bernardo, 2013). The aim was to evaluate the pedestrians' overall view of their walking environment. The purpose was to provide a holistic perspective of how they perceive the built environment of their neighbourhood streets and the level of satisfaction of the current situation. Due to the COVID-19 pandemic and lockdown, we distributed an online questionnaire to users of the three streets. A range of indicators was presented to determine if each met their needs and whether they were successfully designed. The survey results were then compared to the spatial observation of the built environment, and the walkability indices were developed for each street.

Table 2. The proposed model of walkability assessment is based on the 5Cs' layout and their way of measurement.

\begin{tabular}{|c|c|c|c|}
\hline Key Attribute & Parameter & Indicator & Ways of measurement \\
\hline \multirow[t]{6}{*}{ Conspicuous } & \multirow[t]{2}{*}{ Safety } & $\begin{array}{l}\text { Surveillance } \\
\text { Bollards }\end{array}$ & $\begin{array}{l}\text { Number of surveillance cameras and first-floor windows } \\
\text { Number }\end{array}$ \\
\hline & & $\begin{array}{l}\text { Signals and } \\
\text { Signage }\end{array}$ & Number \\
\hline & Security & Lighting & Number of lighting posts \\
\hline & \multirow{3}{*}{$\begin{array}{l}\text { Security } \\
\text { from Traffic }\end{array}$} & Traffic Volume & Number of vehicles per hour \\
\hline & & Traffic Speed & Average speed of vehicles \\
\hline & & Speed Reducers & Number \\
\hline \multirow{2}{*}{$\begin{array}{l}\text { Connectivity } \\
\text { Continuity } \\
\text { Accessibility } \\
\text { Permeability }\end{array}$} & \multirow[t]{2}{*}{ Sidewalks } & Obstructions & Number of obstacles along sidewalks \\
\hline & & $\begin{array}{l}\text { Crossing and } \\
\text { Intersections }\end{array}$ & $\begin{array}{l}\text { Number of services available to aid in crossing and Number of } \\
\text { Intersections }\end{array}$ \\
\hline \multirow{4}{*}{$\begin{array}{l}\text { Convenient } \\
\text { Efficiency } \\
\text { Function }\end{array}$} & \multirow{3}{*}{ Sidewalks } & Sidewalk width & Distance from building elevation to the edge of the curb in $\mathrm{m}$. \\
\hline & & Street Width & $\begin{array}{l}\text { Distance from the edge of curb on one side to the other edge } \\
\text { in } \mathrm{m} \text {. }\end{array}$ \\
\hline & & Buffer Width & Average width of on-street parking in $\mathrm{m}$. \\
\hline & $\begin{array}{l}\text { Land Use } \\
\text { Mix }\end{array}$ & $\begin{array}{l}\text { Active } \\
\text { Environment }\end{array}$ & Number of Public Transport \\
\hline
\end{tabular}




\begin{tabular}{|c|c|c|c|}
\hline & & $\begin{array}{l}\text { Relational } \\
\text { Environment }\end{array}$ & $\begin{array}{l}\text { Area of Food destinations, Facilities and Commercial and } \\
\text { social destinations in } \mathrm{m} 2 \text {. }\end{array}$ \\
\hline \multirow{9}{*}{$\begin{array}{l}\text { Comfortable } \\
\text { Facilities } \\
\text { Aesthetics } \\
\text { Attractiveness }\end{array}$} & $\begin{array}{l}\text { Thermal } \\
\text { Comfort }\end{array}$ & $\begin{array}{l}\text { Shade and rain } \\
\text { cover }\end{array}$ & $\begin{array}{l}\text { Number of shading elements as sheds and trees canopy span } \\
\text { in meters }\end{array}$ \\
\hline & & $\begin{array}{l}\text { Average skyline } \\
\text { height }\end{array}$ & $\begin{array}{l}\text { Height of buildings in meter, to measure average shade of } \\
\text { them in meters }\end{array}$ \\
\hline & Streetscape & Paving Material & Area in $\mathrm{m} 2$ \\
\hline & $\begin{array}{l}\text { and } \\
\text { Landscape }\end{array}$ & Seating Areas & Number \\
\hline & & Trash Receptacles & Number \\
\hline & & Trees & Number \\
\hline & & Landscape strip & Area in m2 \\
\hline & Facilities & $\begin{array}{l}\text { Vehicle Parking } \\
\text { Facilities }\end{array}$ & Area in $\mathrm{m} 2$ \\
\hline & & $\begin{array}{l}\text { Facilities For } \\
\text { Disabled People }\end{array}$ & Number of ramps along the street and sidewalks \\
\hline \multirow{3}{*}{$\begin{array}{l}\text { Convivial } \\
\text { User-friendly } \\
\text { Livable }\end{array}$} & Sociability & Pedestrian Flow & Flow of user number of users per Hour. \\
\hline & & Enclosure & Average building width in meter. \\
\hline & & $\begin{array}{l}\text { Spaces for } \\
\text { interaction }\end{array}$ & Average area of open or green spaces \\
\hline
\end{tabular}

\section{Results and Discussion}

\subsection{Findings from the Literature}

The authors attempt to present a new measurement method that combines the built environment's macro and micro-scale design factors and the common vital concerns on the neighbourhood and street levels. This model for walkability assessment addresses the $5 \mathrm{Cs}$. These fundamental concerns are categorised according to the definition of the $5 \mathrm{Cs}$ and then combined with other attributes; each had a set of parameters with different indicators. These parameters include: $\mathrm{Be}$

1. The connection between pedestrian networks facilitating pedestrian movement and support their trips. Like other research, we assessed this factor using criteria including street permeability and connectivity (Elshater, 2019).

2. Convivial is the quality that can create lively, pleasant, and friendly activity and interaction places. In considering this quality, we include the parameters of liveability and sociability (Elshater, 2020; Shaftoe, 2008).

3. In line with a study conducted on the case of London, the conspicuous quality was recommended to create walkable streets (Transport for London TFL, 2004). This quality of safety and the welcoming nature of the space is affected by the sidewalks, pedestrian paths and public spaces. This design quality relates to spatial legibility, complexity and coherence. Where walking routes are safe, visible, well-lit, and well furnished, in our work, this factor is assessed by criteria regarding route safety and security (Abedo, Salheen, \& Elshater, 2020).

4. In creating comfortable places, this is related to the quality of the walking environment and how the design of these places support the local facilities. Furthermore, having these facilities in place alongside the walkable paths is affected by aesthetics and attractiveness (Abusaada \& Elshater, 2021a).

5. Finally, convivence in the walking experiences is the quality that is affected by the land use through efficiency and functionality (El Helou, 2019; Elshater, 2020).

Based on the above factors and how this research adapted them to the new model, the combined indicator can be defined as a 
compilation of factors from the literature and adapted to the $5 \mathrm{Cs}$ layout to formulate a new set of parameters and indicators for the assessment of built environment attributes to evaluate the walkability of urban streets. We used 26 indicators based on the review of the literature. Table 2 presents a new model of the selected built environment indicators and parameters and their role in the various critical walkability factors. Our results confirmed that the walkability measurement tools are scattered between various forms, such as audits, indices and inventories (Boarnet, Day, Alfonzo, Forsyth, \& Oakes, 2006; Clifton, Smith, \& Rodriguez, 2007; Evenson, et al., 2009; Krambeck \& Shah, 2006).

Walkability has usually been based on the features of the built environment (Forsyth, 2015). Generally, walkability is affected by factors like density (Newman \& Kenworthy, 2006), while mixed land use and connectivity encourage people to walk (Iroz-Elardo, Adkins, \& Ingram, 2021). In addition, the purpose of a walk might be for leisure or to access destinations without using their cars (Lu, Xiao, \& Ye, 2017; Sivam, 2012). Hussein (2018) explained that the built environment and physical features on sidewalks are the primary factors influencing people's walk decisions. His study followed the concept used by Cervero and Kockelman (1997), where they defined the built environment as the physical features of the landscape architecture that mutually set a definition for the public realm of participation in everyday life experience.

According to The Transport for London -TFL (2004) report, a 5C's layout is necessary for a walkable environment. The classification and prioritisation of pedestrians' quality needs are often based on the approach (Refaat \& Kafafy, 2014). Research has suggested design qualities that can support the walkability of the street environment, where the area should be convenient, conspicuous, convivial, comfortable and consistent (5Cs) (Abedo, Salheen, \& Elshater, 2020; Iroz-Elardo, Adkins, \& Ingram, 2021; Transport for London -TFL, 2004). The Public Transport Authority of Australia endorsed the 5C's layout (Australian Public Transport Authority, 2012).

In summary, Table 3 shows the mentioned Key Attributes and walkability concerns in the literature combined with the 5C's approach to develop the model to assess walkability. Consequently, Zayed (2016) deduced that 'walkability' is the extent that an urban context promotes walking. Furthermore, in reviewing relevant literature, there is consensus that the built environment's main physical attributes enhance walkability.

Table 3. Adoption of the walkability requirements and crucial keys driven from literature.

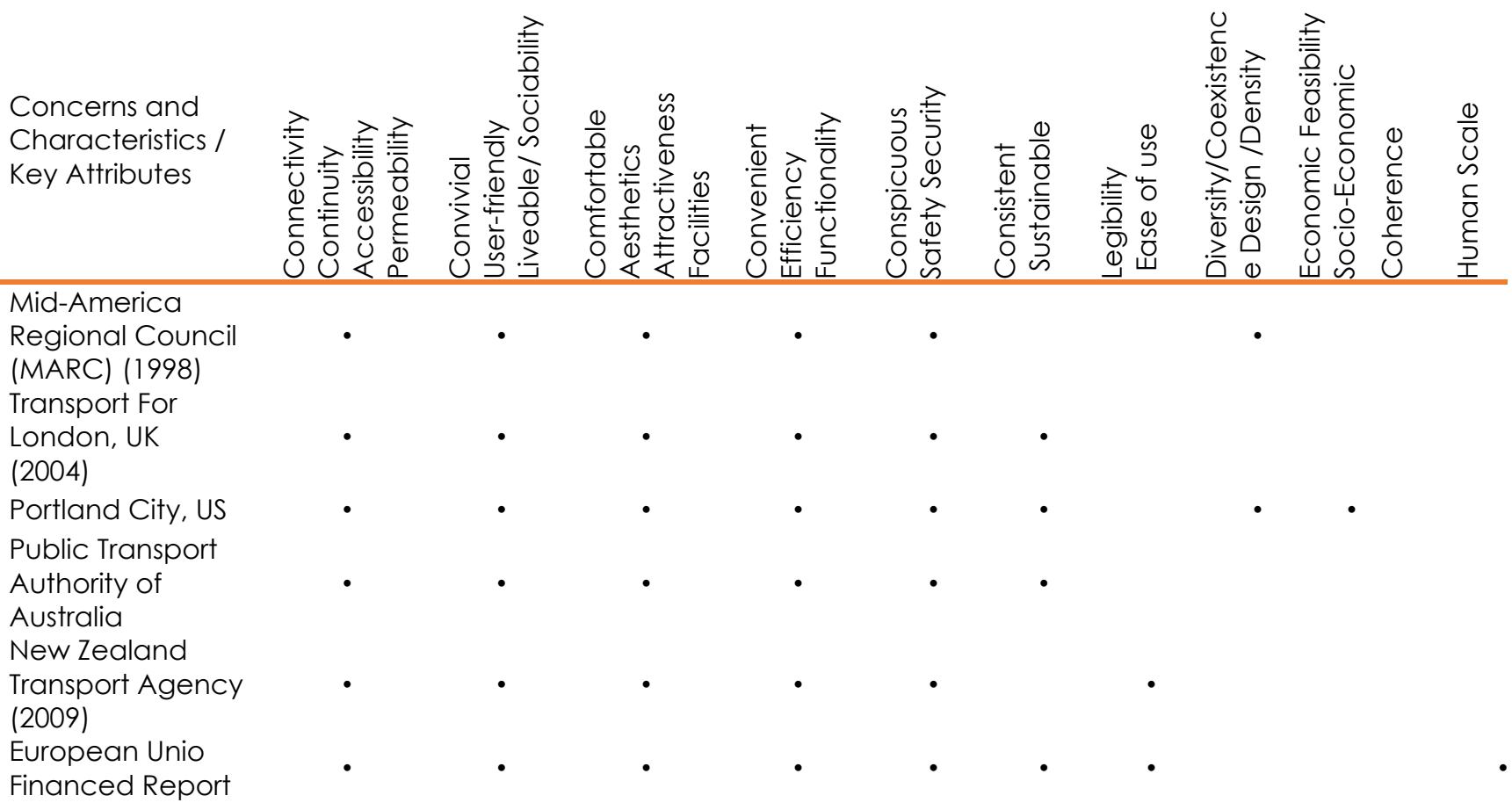


Sheila Ferrer

Tomás Ruiz, Lidón

Mars, (2015)

Handy, Cao\&

Mokhtarian

(2006)

Pikora et al

(2003)

Stevens (2005)

Boarnet et al.

(2007)

Krambeck and

Shah (2006)

Darmoyono and

Tanan (2015)

Forsyth and

Southworth

(2008) Giles-Corti

et al. (2009)

Ewing et al.

(2011) Rebecchi

et al. (2019)

Cevrero and

Kockelman

(1997)

\subsection{Measurable Results}

The LWI was derived for each of the three streets. Therefore, it is critical to determine the street level and the sidewalk amenities to calculate the LWI for each BI indicator and the total LWI for the selected segments. Table 4 shows the LWI for the streets and the level of required improvements (LRI) for the sidewalk BI factors and the entire street environment. For example, the LWI for Talaat Harb Street is 30.99 , with a ' $C$ ' grade indicating that $\mathrm{Bl}$ adequately serves the residents (Table 4). In this neighbourhood, the sidewalk condition is acceptable, but it could be better. In contrast, the LWI ratings of Masr w El Sudan and Abbas
El Akkad streets are 20.94 and 28.45, respectively.

As a result, the grade for these streets is a ' $D$,' as the built environment indicators suggest that these streets are in poor condition and require significant improvement. Across the three selected streets, most $\mathrm{BI}$ indicators received 'poor' or 'awful' LWI ratings, indicating the need for substantial improvements in traffic speed, shade and rain cover, trees, landscape strips, crossing availability, and vehicle facilities. Over the selected streets, few sidewalk factors achieved 'good' or 'very good' LWI ratings, such as the availability of bollards, seating, and enclosures requiring minor improvements.

Table 4. LWI for the selected streets and the LRI.

\begin{tabular}{|c|c|c|c|c|c|c|c|c|c|}
\hline \multirow{3}{*}{$\begin{array}{l}\text { Built } \\
\text { Environment } \\
\text { Indicator }\end{array}$} & \multirow{2}{*}{$\begin{array}{c}\text { Talaat Harb } \\
\text { St. }\end{array}$} & \multirow{2}{*}{$\begin{array}{l}\text { Masr W El } \\
\text { Sudan St. }\end{array}$} & \multirow{2}{*}{$\begin{array}{l}\text { Abbas El- } \\
\text { Akkad St. }\end{array}$} & \multirow{3}{*}{$\begin{array}{l}\text { Indicator } \\
\text { Weightin } \\
\text { g }\end{array}$} & \multicolumn{5}{|c|}{ Local Walkability Index (LWI) \& LRI } \\
\hline & & & & & $\begin{array}{r}\text { Talaat } 1 \\
\text { St. }\end{array}$ & tarb & $\begin{array}{l}\text { Masr V } \\
\text { Sudan }\end{array}$ & & $\begin{array}{l}\text { Abbas El- } \\
\text { Akkad St. }\end{array}$ \\
\hline & $\begin{array}{c}\text { Normalised } \\
\text { Value }\end{array}$ & $\begin{array}{l}\text { Normalise } \\
\text { d Valve }\end{array}$ & $\begin{array}{c}\text { Normalise } \\
\text { d Value }\end{array}$ & & LWI & LRI & LWI & LRI & LWI \\
\hline Surveillance & 6.06 & 7.71 & 6.24 & 5.2 & 31.49 & 4 & 40.07 & 3 & 32.44 \\
\hline Bollards & 16.84 & 1.05 & 2.11 & 5.5 & 92.63 & 1 & 5.79 & 5 & 11.58 \\
\hline Signals and & & & & & & & & & \\
\hline Signage & 10.00 & 2.86 & 7.14 & 5.6 & 56.00 & 3 & 16.00 & 5 & 40.00 \\
\hline Lighting & 8.68 & 6.32 & 5.00 & 4.8 & 41.68 & 3 & 30.32 & 4 & 24.00 \\
\hline Traffic Volume & 5.70 & 6.23 & 8.08 & 4.3 & 24.50 & 4 & 26.77 & 4 & 34.73 \\
\hline Traffic Speed & 6.15 & 4.62 & 9.23 & 3.5 & 21.54 & 4 & 16.15 & 5 & 32.31 \\
\hline
\end{tabular}


Speed

Reducers

Obstructions

3.33

6.49

3.33

$13.33 \quad 2.2$

Crossing

Availability

7.50

8.65

4.86

3.3

Sidewalk width

8.21

6.25

6.25

4.1

1.54

10.26

5.7

Street Width

6.10

2.93

10.98

2.5

Buffer Width

5.00

5.00

10.00

5

Active

Environment

10.00

6.67

3.33

2

Relational

Environment

5.98

4.11

9.91

4

3.49

2.1

8.22

5.5

7.79

5.6

7.22

4.98

13.33

5.7

$3.69 \quad 5.5$

7.08

$3.67 \quad 2.01$

8.67

7.67

14.22

5.78

1.6

12.07

1.1

5.22

5.6

6.67

2.5

4.62

8.1

$\begin{array}{lll}21.84 & 4 & 11.49\end{array}$

6.15

8.74
9.23

8

8

4

1.5

interaction

Overall LWI

Overall level of

required

improvements

$\begin{array}{ccccc}7.33 & 5 & 7.33 & 5 & 29.33 \\ 21.41 & 4 & 28.54 & 4 & 16.05 \\ & & & & \\ 30.75 & 4 & 25.63 & 4 & 25.63 \\ 46.77 & 3 & 8.77 & 5 & 58.46 \\ 15.24 & 5 & 7.32 & 5 & 27.44 \\ 25.00 & 4 & 25.00 & 4 & 50.00\end{array}$

$\begin{array}{lllll}20.00 & 4 & 13.33 & 5 & 6.67\end{array}$

$\begin{array}{lllll}23.92 & 4 & 16.44 & 5 & 39.64\end{array}$

$\begin{array}{lllll}19.33 & 5 & 15.33 & 5 & 7.33\end{array}$

$\begin{array}{lllll}37.67 & 4 & 27.12 & 4 & 45.21\end{array}$

$\begin{array}{lllll}40.44 & 3 & 27.91 & 4 & 43.65\end{array}$

$\begin{array}{lllll}38.00 & 4 & 0.00 & 5 & 76.00\end{array}$

$\begin{array}{lllll}50.77 & 3 & 38.92 & 4 & 20.31\end{array}$

$\begin{array}{lllll}17.42 & 5 & 15.41 & 5 & 7.37\end{array}$

$\begin{array}{lllll}0.00 & 5 & 22.75 & 4 & 9.25\end{array}$

$\begin{array}{lllll}1.22 & 5 & 7.50 & 5 & 13.28\end{array}$

$\begin{array}{lllll}34.09 & 4 & 48.70 & 3 & 29.22\end{array}$

$\begin{array}{ll}5 & 16.67\end{array}$

37.38 
Table 5. Cronbach alpha results

Talaat Harb St. $\quad$ Masr W El Sudan St $\quad$ Abbas El-Akkad St.

\begin{tabular}{|c|c|c|c|}
\hline Surveillance & 0.77 & 0.98 & 0.99 \\
\hline Bollards & 0.81 & 0.96 & 0.95 \\
\hline Signals and Signage & 0.83 & 0.94 & 0.97 \\
\hline Lighting & 0.84 & 0.94 & 0.96 \\
\hline Traffic Volume & 0.85 & 0.96 & 0.96 \\
\hline Traffic Speed & 0.86 & 0.98 & 0.97 \\
\hline Speed Reducers & 0.85 & 0.94 & 0.98 \\
\hline Obstructions & 0.84 & 0.94 & 0.97 \\
\hline Crossing Availability & 0.82 & 0.97 & 0.93 \\
\hline Sidewalk width & 0.85 & 0.98 & 0.97 \\
\hline Street Width & 0.84 & 0.94 & 0.94 \\
\hline Buffer Width & 0.85 & 0.96 & 0.99 \\
\hline Active Environment & 0.85 & 0.96 & 0.95 \\
\hline Relational Environment & 0.85 & 0.96 & 0.98 \\
\hline Shade and rain cover & 0.83 & 0.94 & 0.95 \\
\hline Average skyline height & 0.83 & 0.94 & 0.95 \\
\hline Paving Material & 0.83 & 0.99 & 0.91 \\
\hline Seating Areas & 0.82 & 0.92 & 0.98 \\
\hline Trash Receptacles & 0.85 & 0.96 & 0.96 \\
\hline Trees & 0.87 & 0.95 & 0.99 \\
\hline Landscape strip & 0.87 & 0.98 & 0.99 \\
\hline Vehicle Parking Facilities & 0.83 & 0.90 & 0.97 \\
\hline Facilities for Disabled People & 0.85 & 0.97 & 0.98 \\
\hline Pedestrian Flow & 0.79 & 0.90 & 0.96 \\
\hline Enclosure & 0.86 & 0.97 & 0.97 \\
\hline Spaces for interaction & 0.97 & 0.95 & 0.97 \\
\hline
\end{tabular}

\subsection{Survey Results}

The online questionnaire results were obtained after three days, the total number of respondents was 387. Table 6 shows the respondents' characteristics.

Table 6. Socio-demographic characteristics of the respondents.

\begin{tabular}{|c|c|c|c|c|c|c|}
\hline \multirow[t]{2}{*}{ Characteristic } & \multicolumn{2}{|c|}{$\begin{array}{l}\text { Talaat Harb St. } \\
(n=112)\end{array}$} & \multicolumn{2}{|c|}{$\begin{array}{l}\text { Masr W El Sudan St } \\
(n=107)\end{array}$} & \multicolumn{2}{|c|}{ Abbas El-Akkad St. $(n=168)$} \\
\hline & $\mathrm{N} \mathrm{F}$ & Percentage \% & $\mathbf{N}$ & Percentage \% & $\mathbf{N}$ & Percentage \% \\
\hline \multicolumn{7}{|l|}{ Gender } \\
\hline Male & 46 & 41.1 & 39 & 36.4 & 65 & 38.7 \\
\hline $\begin{array}{l}\text { Female } \\
\text { Age }\end{array}$ & \multicolumn{5}{|c|}{ Age } & 61.3 \\
\hline $18-26$ & 34 & 30 & 33 & 30.8 & 41 & 24.4 \\
\hline $27-31$ & 27 & 24.1 & 29 & 27.1 & 82 & 48.8 \\
\hline $32-46$ & 25 & 22.3 & 19 & 17.8 & 23 & 13.7 \\
\hline $47-60$ & 19 & 16.9 & 21 & 19.6 & 19 & 11.3 \\
\hline $60+$ & 7 & 6.7 & 5 & 4.7 & 3 & 1.8 \\
\hline \multicolumn{7}{|l|}{$\begin{array}{l}\text { Duration of the } \\
\text { walk }\end{array}$} \\
\hline $\begin{array}{l}\text { Less than } 10 \\
\text { minutes }\end{array}$ & 26 & 23.21 & 26 & 24.3 & 25 & 14.9 \\
\hline
\end{tabular}




\begin{tabular}{|c|c|c|c|c|c|c|}
\hline 10-19 minutes & 25 & 22.32 & 28 & 26.2 & 73 & 43.5 \\
\hline 20-29 minutes & 34 & 30.36 & 19 & 17.8 & 43 & 25.6 \\
\hline $\begin{array}{l}30 \text { minutes or } \\
\text { more }\end{array}$ & 27 & 24.11 & 34 & 31.8 & 27 & 16.1 \\
\hline \multicolumn{7}{|l|}{ Type of Users } \\
\hline Resident & 22 & 19.30 & 24 & 21.30 & 21 & 18.40 \\
\hline $\begin{array}{l}\text { Going to } \\
\text { school/ Work }\end{array}$ & 20 & 18.20 & 23 & 20.80 & 20 & 17.60 \\
\hline $\begin{array}{l}\text { Exercise } \\
\text { /sports }\end{array}$ & 4 & 3.50 & 9 & 7.60 & 4 & 3.30 \\
\hline $\begin{array}{l}\text { Going to bus } \\
\text { stop/public }\end{array}$ & & 6.70 & & 5.60 & & 6.60 \\
\hline transportation. & 8 & & 6 & & 7 & \\
\hline $\begin{array}{l}\text { Going to a } \\
\text { daily service }\end{array}$ & 13 & 11.70 & 14 & 12.50 & 12 & 11.00 \\
\hline $\begin{array}{l}\text { Shopping } \\
\text { Vicit }\end{array}$ & 51 & 45.70 & 45 & 40.30 & 52 & 46.30 \\
\hline $\begin{array}{l}\text { Visit } \\
\text { neighbours or }\end{array}$ & & 20.10 & & 22.30 & & 19.50 \\
\hline relatives & 23 & & 25 & & 22 & \\
\hline $\begin{array}{l}\text { Enjoy the } \\
\text { outdoors }\end{array}$ & 14 & 12.30 & 13 & 11.60 & 12 & 10.40 \\
\hline
\end{tabular}

\section{Discussion}

Our findings identified relationships between the survey results and LWI values of three streets for the 5Cs' attributes, parameters, and indicators. User satisfaction for the three streets regarding the attribute of 'conspicuous' was less than the calculated indices for the attributes. There was a difference between the results for 'comfortable' compared to convivial and convenience attributes. The level of user satisfaction was higher than the calculated indices (Figure 3a).

The results confirm the importance of including users' perceptions and their satisfaction in perceiving the built environments to achieve the highest walkability indices. The result of the survey and the LWI for the 5Cs' attributes proved that people's perception of the three streets regarding conspicuousness is less than the measured index. Regarding convenience and conviviality, there was a slight difference between the two measures. However, for comfort, users showed high levels of more than the measured indices. The relationship between survey results and the measured indices differs from the parameters. The results here show that people's satisfaction level with safety from traffic is less than their index indicates for the three streets. While the quantitative assessment of the safety parameter was measured to be high, users did not feel safe from traffic, so the measure does not appear to meet the objective. Vice-versa, for the mixture of land uses, the satisfaction level is higher than the measured index that indicates applying all types of uses does not fulfil people's needs. Both indices and satisfaction are nearly equal in the three streets (Figure 3). Our results about walkability parameters in Egyptian cases align with other research that confirmed effective land use could promote walkability (Abedo, Salheen, \& Elshater, 2020; Abussada \& Elshater, 2021 b; Balsas, 2021; Lu, Xiao, \& Ye, 2017). Furthermore, these results demonstrated in this paper match state-of-the-art methods. Finally, the results from Egyptian cases confirm previous studies, where a convenient environment facilitates residents to go on food in their daily lives and walk for their commute (Elshater, 2020; Hussein, 2018).

Because of the inability to face-to-face interview residents, we decided not to investigate users' satisfaction using an online survey. One concern about the survey findings was that we used a limited sample size. Another limitation in the walkability investigation involves using various methods like space syntax or Walk Score to verify the numerical results of normalisation for positive and negative indicators.

The present findings confirm that 12 out of the 26 indicators were the most effective based on their opinions. However, their level of satisfaction was nearly equal to the calculated indices on the three streets (Figure 3c). In sum, 
these results show a gap between the level of satisfaction and how they perceive the walking environment and the theoretical framework for achieving a walkable street.

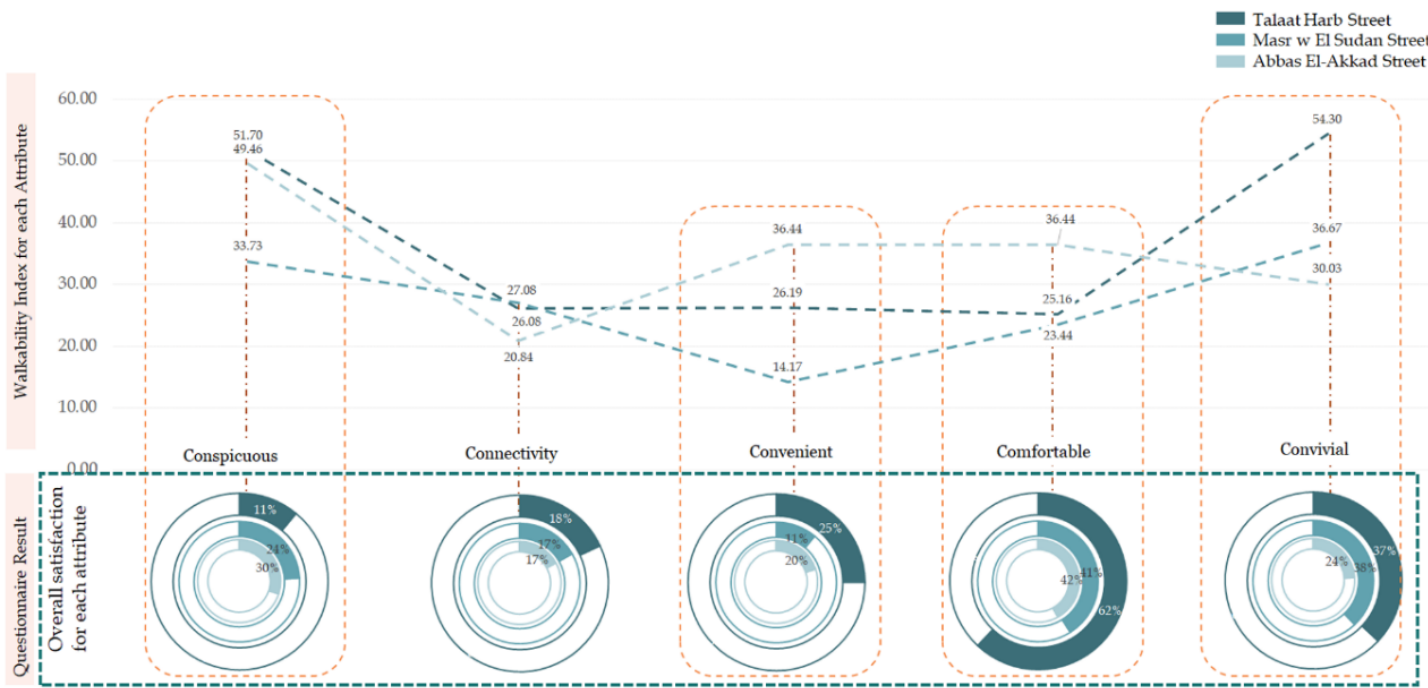

(a) Relation between Questionnaire results and LWI for the 5 Cs' Attributes

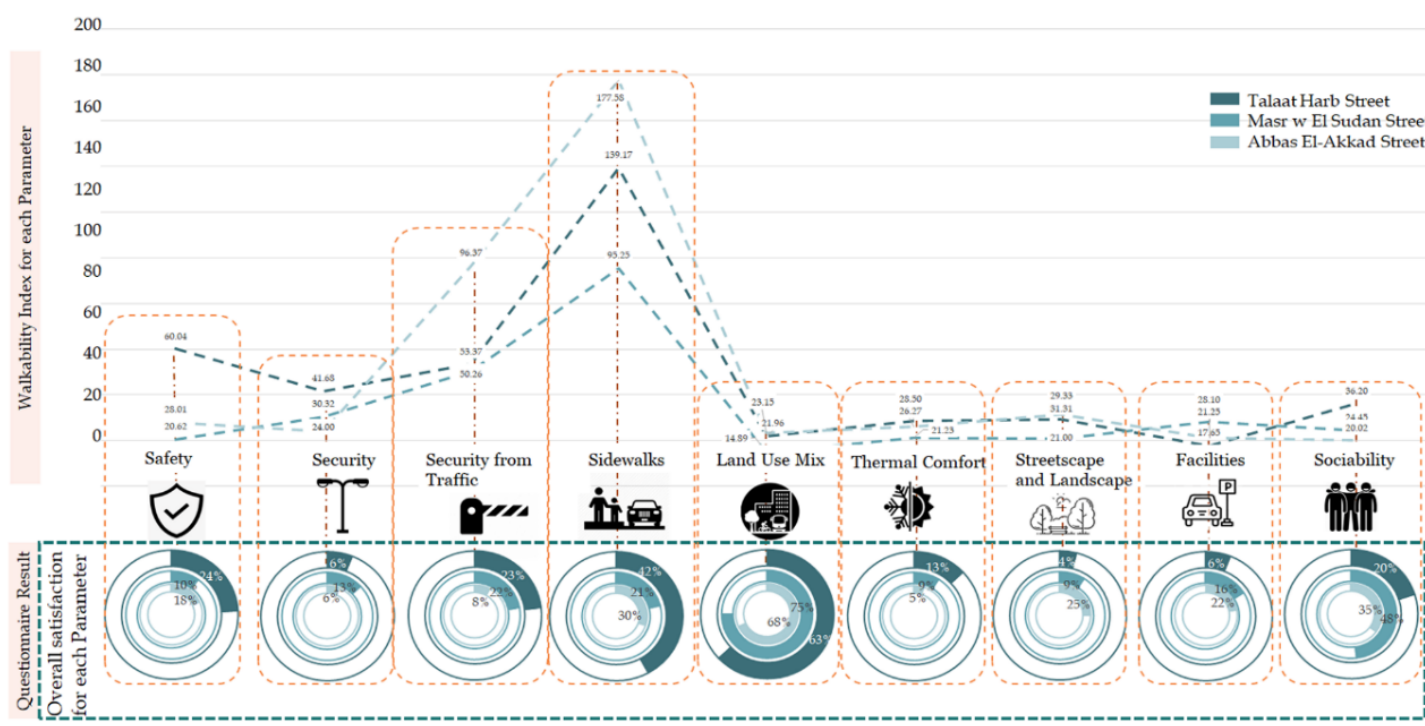

(b) Relation between Questionnaire results and LWI for the Parameters

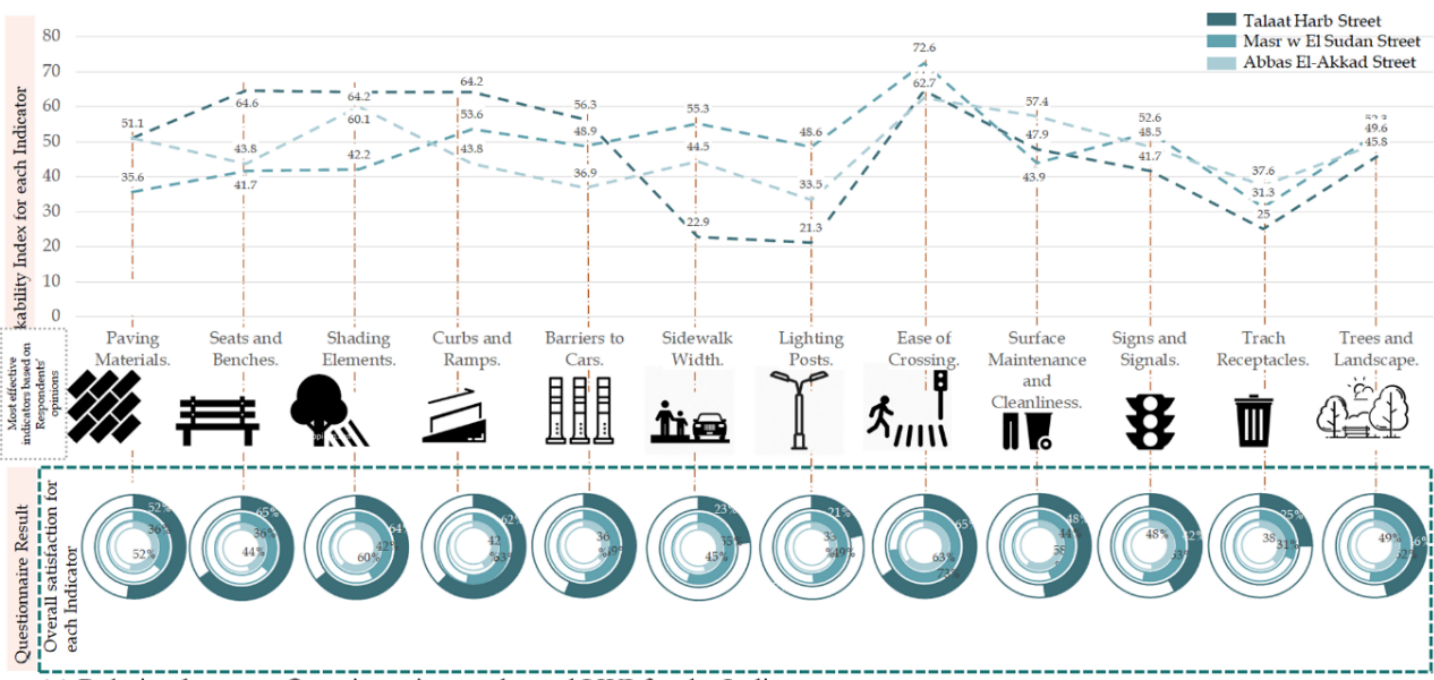

(c) Relation between Questionnaire results and LWI for the Indicators

Figure 3. Relation between survey results and LWI for the indicators. 
The further novel finding on the parameters is that the relationship between questionnaire results and LWIs had a colossal difference. For 'safety from traffic', the index obtained was higher than the level of satisfaction, and visaversa with 'land use mix', and for 'sidewalks.' It had the most significant difference as the walkability indices were higher than the level of satisfaction (Figure 3b).

The added value of this research is in comparing the measured walkability indices for the built environment, which the authors have developed with users' level of satisfaction using a survey. This research breaks new ground in highlighting the importance of perceptions of the built environment on their walking behaviour. In this respect, investigating people's perceptions and the most effective indicators should be considered in developing local walkability.

\section{Conclusion}

This study looked at 26 environmental indicators that affect walkability on Cairo's streets, divided into nine parameters and five categories. A new compliance measuring method that combines the built environment's macro-and micro-scale design indicators and the common vital concerns mentioned in literature at the neighbourhood and streetlevel addressed to the 5Cs, was presented. Using this method to calculate the walkability indices for the selected streets in Cairo and comparing the resulting index to the respondents' answers and their level of satisfaction from the developed questionnaire could help decision-makers determine the features of the built environment that needs development to achieve more walkability levels. This spectrum of indicators can make this tool universally applicable. A single walkability index was developed by providing indicator weights based on their relevance and importance, then combining them. Finally, the reliability of the built environment indicators used in the LWI was tested using an internal consistency test. All indicators showed moderate to high reliability across the studied neighbourhoods.

Due to the limitations resulting from the COVID19 pandemic and lockdown, future research should consider measuring perceptions and satisfaction with a range of on-site questionnaires, field studies, semi-structured interviews and analysis of the indicators. Multi- disciplinary approaches are also helpful, and the research should include input from urban planners, designers, sociologists and health care professionals. Based on the research limitations, future work includes an extensive study of streets in neighbourhoods of varying character, considering the design of new cities and how urban planners and governmental authorities plan them. Other quantitative measuring tools could be adopted alongside the established $\mathrm{WI}$ and the questionnaire.

\section{Acknowledgement}

This research did not receive any specific grant from funding agencies in the public, commercial, or not-for-profit sectors.

\section{Conflict of interests}

The authors declare no conflict of interest.

\section{References}

Abedo, M., Salheen, M., \& Elshater, A. (2020). The Dawn of Walkability. In Humanizing Cities Through Car-Free City Development and Transformation (pp. 98-114). IGI Global. https://doi.org/10.4018/978-17998-3507-3.ch004

Abusaada, H., \& Elshater, A. (2021a). Revealing distinguishing factors between Space and Place in urban design literature. Journal of Urban Design, 26(3), 319-340. https://doi.org/10.1080/13574809.2020.1832887

Abusaada, H., \& Elshater, A. (2021b). Effect of people on placemaking and affective atmospheres in city streets. Ain Shams Engineering Journal. https://doi.org/10.1016/j.asej.2021.04.019

Abusaada, H., Vellguth, C., \& Elshater, A. (2019). Handbook of Research on Digital Research Methods and Architectural Tools in Urban Planning and Design. IGI Global. https://doi.org/10.4018/978-15225-9238-9

Aghaabbasi, M., Moeinaddini, M., Zaly Shah, M., \& Asadi-Shekari, Z. (2017). A new assessment model to evaluate the microscale sidewalk design factors at the neighbourhood level. Journal of Transport \& Health, 5, 97-112. https://doi.org/10.1016/j.jth.2016.08.012

Al-shabeeb, A. R. R. (2015). A modified analytical hierarchy process method to select sites for groundwater recharge in Jordan University of Leicester, Doctor of Philosophy (PhD)]. http://www.secheresse.info/spip.php?article56306 
Alawadi, K., Hernandez Striedinger, V., Maghelal, P., \& Khanal, A. (2021). Assessing walkability in hot arid regions: the case of downtown Abu Dhabi. URBAN DESIGN International, $1-21$. https://doi.org/10.1057/s41289-021-00150-0

Albers, P. N., Wright, C., \& Olwoch, J. (2010). Developing a South African pedestrian environment assessment tool: Tshwane case study. South African Journal of Science, 106(9), 1-8. https://doi.org/10.4102/sajs.v106i9/10.187

Alfonzo, M. A. (2005). To Walk or Not to Walk? The Hierarchy of Walking Needs. Environment and Behavior, 37(6), 808-836. https://doi.org/10.1177/0013916504274016

Arellana, J., Alvarez, V., Oviedo, D., \& Guzman, L. A. (2021). Walk this way: Pedestrian accessibility and equity in Barranquilla and Soledad, Colombia. Research in Transportation Economics, 86, 101024. https://doi.org/10.1016/j.retrec.2020.101024

Arellana, J., Saltarín, M., Larrañaga, A. M., Alvarez, V., \& Henao, C. A. (2020). Urban walkability considering pedestrians' perceptions of the built environment: a 10-year review and a case study in a medium-sized city in Latin America. Transport Reviews, 40(2), 183-203. https://doi.org/10.1080/01441647.2019.1703842

Australian Public Transport Authority. (2012). Planning and designing for pedestrians: guidelines https://www.transport.wa.gov.au/mediaFiles/activetransport/AT WALK P plan_design_pedestrians_g uidelines.pdf

Balsas, C. J. L. (2021). Exciting walk-only precincts in Asia, Europe and North-America. Cities, 112, 1-13. https://doi.org/10.1016/j.cities.2021.103129

Banister, D. (2007). SUSTAINABLE TRANSPORT: CHALLENGES AND OPPORTUNITIES. Transportmetrica, 3(2), 91-106. https://doi.org/10.1080/18128600708685668

Batista e Silva, J., da Graça Saraiva, M., Loupa Ramos, I., \& Bernardo, F. (2013). Improving Visual Attractiveness to Enhance City-River IntegrationA Methodological Approach for Ongoing Evaluation. Planning Practice \& Research, 28(2), 163-185.

https://doi.org/10.1080/02697459.2012.704734

Boarnet, M. G., Day, K., Alfonzo, M., Forsyth, A., \& Oakes, M. (2006). The Irvine-Minnesota Inventory to Measure Built Environments: Reliability Tests. American Journal of Preventive Medicine, 30(2), 153-159.e143.

https://doi.org/10.1016/j.amepre.2005.09.018

Capitanio, M. (2019). Attractive streetscape making pedestrians walk longer routes: The case of Kunitachi in Tokyo. Journal of Architecture and Urbanism, 43(2),

131-137.

https://doi.org/10.3846/jau.2019.10359

CAPMAS. (2019). Egypt statistics. Retrieved from Central Agency for Public Mobilization. https://www.capmas.gov.eg/HomePage.aspx

Caymaz, G. F. Y. (2019). The effects of built environment landscaping on site security: reviews on selected shopping centers in İstanbul. Journal of Contemporary Urban Affairs, 3(1), 191-201. https://doi.org/10.25034/IJCUA.2018.4730

Cervero, R., \& Kockelman, K. (1997). Travel demand and the 3Ds: Density, diversity, and design. Transportation Research Part D: Transport and Environment, 2(3), 199-219. https://doi.org/10.1016/S1361-9209(97)00009-6

Chapman, J., \& Olson, J. (2017). Calgary's Pedestrian Strategy: Inception to Implementation (breakout presentation). Journal of Transport \& Health, 7, S35. https://doi.org/10.1016/j.jth.2017.11.057

Clifton, K. J., Livi Smith, A. D., \& Rodriguez, D. (2007). The development and testing of an audit for the pedestrian environment. Landscape and Urban Planning, $\quad$ 80(1), 95-110 https://doi.org/10.1016/j.landurbplan.2006.06.008

Cortina, J. M. (1993). What is coefficient alpha? An examination of theory and applications. Journal of applied psychology, 78(1), 98-104. https://doi.org/10.1037/0021-9010.78.1.98

Department of Public Health. (2008). The Pedestrian Environmental Quality Index (PEQI): An assessment of the physical condition of streets and intersections. San Francisco: Program on Health, Equity, and Sustainability Urban Health and Place Team Department.

https://merritt.cdlib.org/d/ark $\% 3 \mathrm{~A} \% 2 \mathrm{~F} 13030 \% 2 \mathrm{Fm}$ 5gf27pt/1/producer\%2F892138562.pdf

Dill, J. (2004). Measuring network connectivity for bicycling and walking In 83rd annual meeting of the Transportation Research Board, Washington, DC. TRB 2004 Annual Meeting CD-ROM, https://repository.difu.de/jspui/bitstream/difu/12615 6/1/DB0499.pdf

El Helou, M. A. (2019). Shaping the city that decreases overweight and obesity through healthy built 
environment. Journal Of Contemporary Urban Affairs, 3(2), 16-27. https://doi.org/10.25034/ijcua.2018.4697

Elshater, A. (2019). The Predicament of PostDisplacement Amidst Historical Sites: A Designbased Correlation Between People and Place. Heritage \& Society, 12(2-3), 85-115. https://doi.org/10.1080/2159032X.2021.1879355

Elshater, A. (2020). Food consumption in the everyday life of liveable cities: design implications for conviviality. Journal of Urbanism: International Research on Placemaking and Urban Sustainability, $13(1)$, 68-96. https://doi.org/10.1080/17549175.2019.1666026

Elshater, A., Abusaada, H., \& Afifi, S. (2019). What makes livable cities of today alike? Revisiting the criterion of singularity through two case studies. Cities, 92, 273-291. https://doi.org/10.1016/i.cities.2019.04.008

Evenson, K. R., Sotres-Alvarez, D., Herring, A. H., Messer, L., Laraia, B. A., \& Rodríguez, D. A. (2009). Assessing urban and rural neighborhood characteristics using audit and GIS data: derivation and reliability of constructs. International Journal of Behavioral Nutrition and Physical Activity, 6(1), 44. https://doi.org/10.1186/1479-5868-6-44

Ewing, R., Greenwald, M., Zhang, M., Walters, J., Feldman, M., Cervero, R., Frank, L., \& Thomas, J. (2011). Traffic generated by mixed-use developments - six-region study using consistent built environmental measures. Journal of Urban Planning and Development, 137(3), 248-261. https://doi.org/10.1061/(asce)up.19435444.0000068

Ewing, R., \& Handy, S. (2009). Measuring the Unmeasurable: Urban Design Qualities Related to Walkability. Journal of Urban Design, 14(1), 65-84. https://doi.org/10.1080/13574800802451155

Ferrer, S., Ruiz, T., \& Mars, L. (2015). A qualitative study on the role of the built environment for short walking trips. Transportation Research Part F: Traffic Psychology and Behaviour, 33, 141-160. https://doi.org/10.1016/j.trf.2015.07.014

Forsyth, A. (2015). What is a walkable place? The walkability debate in urban design. URBAN DESIGN International, 20(4), 274-292. https://doi.org/10.1057/udi.2015.22

Forsyth, A. N. N., \& Southworth, M. (2008). Cities Afoot-Pedestrians, Walkability and Urban Design.
Journal of Urban Design, 13(1), 1-3. https://doi.org/10.1080/13574800701816896

Gallin, N. (2001). Quantifying pedestrian friendliness-guidelines for assessing pedestrian level of service. Road \& Transport Research, 10(1), 47-55. https://www.proquest.com/docview/215248261?pqorigsite $=$ gscholar $\&$ fromopenview $=$ true

Hussein, N. (2018). The pedestrianisation and its relation with enhancing walkability in urban spaces. Journal Of Contemporary Urban Affairs, 2(1), 102-112. https://doi.org/10.25034/ijcua.2018.3666

Iroz-Elardo, N., Adkins, A., \& Ingram, M. (2021). Measuring perceptions of social environments for walking: A scoping review of walkability surveys. Health \& Place, 67, 102468. https://doi.org/10.1016/j.healthplace.2020.102468

Krajnc, D., \& Glavič, P. (2005). A model for integrated assessment of sustainable development. Resources, Conservation and Recycling, 43(2), 189-208. https://doi.org/10.1016/j.resconrec.2004.06.002

Krambeck, H. V. (2006). The Global Walkability Index. Cambridge: Massachusetts Institute of Technology (MIT). https://dspace.mit.edu/handle/1721.1/34409

Leslie, E., Coffee, N., Frank, L., Owen, N., Bauman, A., \& Hugo, G. (2007). Walkability of local communities: Using geographic information systems to objectively assess relevant environmental attributes. Health \& Place, 13(1), 111-122. https://doi.org/10.1016/j.healthplace.2005.11.001

Lo, R. H. (2009). Walkability: what is it? Journal of Urbanism: International Research on Placemaking and Urban Sustainability, 2(2), 145-166. https://doi.org/10.1080/17549170903092867

Lopez, M. C. R., Toan, T. D., \& Wong, Y. D. (2020). Transitioning Different Stages of Transport Planning in Urban Areas: Experiences of Singapore and Vietnam. In CIGOS 2019, Innovation for Sustainable Infrastructure (pp. 953-958). Springer. https://doi.org/10.1007/978-981-15-0802-8_152

Lu, Y., Xiao, Y., \& Ye, Y. (2017). Urban density, diversity and design: Is more always better for walking? A study from Hong Kong. Preventive Medicine, 103, S99-S103. https://doi.org/10.1016/j.ypmed.2016.08.042

Nardo, M., Saisana, M., Saltelli, A., \& Tarantola, S. (2005). Tools for composite indicators building. Ispra: Institute for the Protection and Security of the Citizen. 
http://citeseerx.ist.psu.edu/viewdoc/download?doi=1 $\underline{0.1} 1.958 .2519 \& \mathrm{rep}=\mathrm{rep} 1 \&$ type $=\mathrm{pdf}$

Newman, P., \& Kenworthy, J. (2006). Urban Design to Reduce Automobile Dependence. Opolis: An International Journal of Suburban and Metropolitan Studies, 2(1), 35-52. https://escholarship.org/uc/item/2b76f089

OECD, European Union, \& - European Commission, Joint Research C. (2008). Handbook on Constructing Composite Indicators: Methodology and User Guide. OECD Publishing.

https://doi.org/10.1787/533411815016

Pallas, T. (2010). The Pedestrian Access Strategy: A strategy to increase walking for transport in Victoria. https://www.victoriawalks.org.au/Assets/Files/Pedes trian $\% 20$ Access $\% 20$ Strategy $\% 20$ final $\% 20 \mathrm{WEB} \% 2$ 0version.pdf

Pucher, J., \& Buehler, R. (2010). Walking and cycling for healthy cities. Built environment, 36(4), 391-414. https://doi.org/10.2148/benv.36.4.391

Refaat, H., \& Kafafy, N. (2014). Approaches and lessons for enhancing walkability in cities: a landscape conceptual solution for Talaat Harb Street, Cairo. International Journal of Education and Research, 2(6), 301-322. http://www.ijern.com/journal/June2014/24.pdf

Reisi, M., Nadoushan, M. A., \& Aye, L. (2019). Local walkability index: assessing built environment influence on walking. Bulletin of Geography. Socioeconomic Series, 46(46), 7 - 21. https://doi.org/10.2478/bog-2019-0031

Rojas López, M. C., \& Wong, Y. D. (2019). Process and determinants of mobility decisions - A holistic and dynamic travel behaviour framework. Travel Behaviour and Society, 17, 120-129. https://doi.org/10.1016/j.tbs.2019.08.003

Saaty, T. (1979). The Analytic Hierarchy Process: Planning, Priority Setting, Resource Allocation (Decision Making Series). https://doi.org/10.21236/ADA214804

Shaaban, K. (2019). Assessing Sidewalk and Corridor Walkability in Developing Countries. Sustainability, 11(14), 3865. https://doi.org/10.3390/su11143865
Shaftoe, H. (2008). Convivial Urban Spaces Creating Effective Public Places (1st ed.). London: Earthscan. https://doi.org/10.4324/9781849770873

Sivam, A., Karuppannan, S., Koohsari, M. J., \& Sivam, A. (2012). Does urban design influence physical activity in the reduction of obesity? A review of evidence. The Open Urban Studies Journal, 5(1), 14 21. https://doi.org/10.2174/1874942901205010014

Soba, M., Ersoy, Y., Tarakcioğlu Altınay, A., Erkan, B., \& Şik, E. (2020). Application of Multiple Criteria Decision-Making Methods in Assignment Place Selection. Mathematical Problems in Engineering, 2020, 1-12. https://doi.org/10.1155/2020/6748342

Southworth, M. (2005). Designing the walkable city. Journal of Urban Planning and Development, 131(4), 246-257. https://doi.org/10.1061/(asce)0733$\underline{9488(2005) 131: 4(246)}$

Transport for London. (2004). Making London a walkable city: The walking plan for London. London. https://fussverkehr.ch/wordpress/wpcontent/uploads/2016/09/walking-plan-2004.pdf

Un-Habitat. (2013). Planning and Design for Sustainable Urban Mobility: Global Report on Human Settlements 2013. New York: UN Habitat. https://doi.org/10.4324/9781315857152

US News. (2021). Best Countries 2021: Global rankings, international news and data insights. Philadelphia: U.S.News \& World Report LP A. https://www.usnews.com/media/bestcountries/overall-rankings-2021.pdf

Wahba, S., Kamel, B., Kandil, A., \& Fadda, N. (2020). Pedestrian mall as an enabler to enhance street life and promote walkability in downtown cairo. Journal of Engineering and Applied Science, 67(3), 565-584. https://fount.aucegypt.edu/faculty journal articles/8 $\underline{96 /}$

Zayed, M. A. A. (2016). The effect of landscape elements on walkability in Egyptian gated communities. Archnet-IJAR, Archnet International Journal of Architectural Research, 10(2), 113-129. https://doi.org/10.26687/archnet-ijar.v10i2.956

How to cite this article:

Tarek, M., Hassan, G. F., Elshater, A., \& Elfayoumi, M. (2021). Investigating Built Environment Indicators to Develop a Local Walkability Index. Journal of Contemporary Urban Affairs, 5(2), 235-251. https://doi.org/10.25034/ijcua.2021.v5n2-7 